\title{
Effects of tricresylphosphate on esterase activity of rat serum and tissues
}

\author{
M. MANNO ${ }^{1}$, F. RIGONI ${ }^{2}$, G. B. BARTOLUCCI ${ }^{1}$, M. BIANCHI ${ }^{2}$, AND \\ M. MAZZOTTA ${ }^{1}$
}

From the ${ }^{1}$ Institute of Industrial Medicine and the ${ }^{2}$ Institute of Biological Chemistry, University of Padova, Italy

ABSTRACT The effect of tricresylphosphate (TCP) was studied in vitro and in vivo on the rat liver and brain enzymes acetylcholinesterase (ACC), butyrylcholinesterase (CHE), arylesterase (ARE), aliesterase (ALI), and the microsomal nicotinamide-adenine dinucleotide phosphate oxidase ( $\mathrm{NADPH}_{2}$-oxidase) system. The results show that, in the male rat, TCPgiven intraperitoneally induces an increase in liver microsomal ARE and $\mathrm{NADPH}_{2}$-oxidase and a decrease in ALI and cholinesterase; no activation of $\mathrm{ARE}$ and $\mathrm{NADPH}_{2}$-oxidase is observed in female rats.

It is now generally accepted that the reaction of organophosphate esters with esterases is the same process that occurs when such enzymes catalyse the hydrolysis of their substrates (Aldridge and Barnes, 1961, 1966; Aldridge and Reiner, 1972).

Inhibition of aliesterase (ALI) after treatment with triortholylphosphate was demonstrated by Dubois (1972) and the toxicity of another phosphoric ester, malathion, appeared to be increased when ALI activity was low.

The aim of the present study was to establish whether tricresylphosphate (TCP) can affect microsomal enzymes in rat liver and brain. The activity of rat serum was considered together with microsomal nicotinamide-adenine dinucleotide phosphatedependent ( $\mathrm{NADPH}_{2}$-dependent) oxidase and nonspecific esterases. The effect of $n$-hexane administration, alone or with TCP, was also studied because $\mathrm{n}$-hexane is a volatile organic solvent widely employed in the same type of technological processes in which TCP is used.

\section{Methods}

ANIMALS AND TREATMENT

Twenty male Wistar albino rats weighing 100-120 g were injected intraperitoneally (i.p.) with $1 \%$ orthotricresylphosphate (Disflamoll Farbenfabriken Bayer Aktiengesellschaft, Leverkusen) dissolved in olive

Address for correspondence: Dr F. Rigoni, Institute of Biological Chemistry, via Marzolo 3, 35100, Padova, Italy.

Received for publication 8 February 1978

Accepted for publication 28 June 1978 oil, at a daily dose rate of $2 \cdot 8 \mathrm{~g} \mathrm{TCP} / \mathrm{kg} /$ day for 3 days.

A group of 30 male and 30 female rats was injected i.p. with n-hexane (Hexanes, Analytical Reagent, Mallincrodt Chemical Works, St Louis) $(2 \cdot 8 \mathrm{~g} / \mathrm{kg} / \mathrm{day}$ for 3 days), TCP $(2 \cdot 8 \mathrm{~g} / \mathrm{kg} /$ day for 3 days) and $\mathrm{n}$ hexane plus TCP at the same dose level. Control animals received corresponding quantities of the vehicle.

A parallel study was carried out with 24 male and 24 female rats exposed to an atmosphere of $500 \mathrm{ppm}$ n-hexane for 3 days in an exposure room (Peretti and Bombi, 1975). In this experiment some animals were pretreated with TCP $(2 \cdot 8 \mathrm{~g} / \mathrm{kg} /$ day for 3 days $)$ before exposure, and TCP was administered percutaneously, being applied directly to $2 \mathrm{~cm}^{2}$ of shaven skin.

LIVER AND BRAIN PREPARATION

The rats were decapitated at the end of the intoxication period (12 $\mathrm{h}$ after the last dose). The liver and the brain were removed immediately and cooled in an ice bath. Homogenates $(0.25 \mathrm{~g}$ fresh tissue $/ \mathrm{ml})$ were prepared with a cold $0.25 \mathrm{M}$ sucrose solution using a Teflon glass Potter homogeniser. The mitochondrial fraction was obtained from the homogenates by centrifugation in a Sorvall centrifuge at $4000 \mathrm{~g}$ for $2 \mathrm{~min}$ to remove the nuclear fraction. The supernatant was then spun at $6000 \mathrm{~g}$, the sediment discarded and the new supernatant spun at $10000 \mathrm{~g}$. The sediment from this last step was resuspended in $1 \mathrm{ml}$ of $0.25 \mathrm{M}$ sucrose and the pellet sedimenting between $6000 \mathrm{~g}$ and $10000 \mathrm{~g}$ was taken as the mito- 
chondrial fraction. The mitochondrial pellet was gently resuspended with $1 \mathrm{ml}$ of $0.25 \mathrm{M}$ sucrose and cooled to $0^{\circ} \mathrm{C}$ using the homogeniser to obtain a uniform suspension.

For preparation of the microsomal fraction the $9000 \mathrm{~g}$ supernatant was centrifuged in a Spinco L-50 ultracentrifuge at $105000 \mathrm{~g}$ for $50 \mathrm{~min}$. The microsomal pellet thus obtained was resuspended with $0.25 \mathrm{M}$ sucrose solution at $0^{\circ} \mathrm{C}$. The fractionation procedures are similar to those of Schneider (1964).

PROTEIN ASSAY

Protein was determined according to the method of Gornall et al. (1949), using bovine serum albumin (Sigma, St Louis, Type V) as a standard.

\section{ENZYME ASSAY}

Acetylcholinesterase and butyrylcholinesterase activity were assayed according to the method of Ellman et al. (1961). Acetylthiocholine iodide and butyrylthiocholine iodide obtained from Boehringer, Mannheim, Germany, were used as substrates.

ARE was measured by a kinetic method (Burlina and Galzigna, 1972) based on the hydrolysis of $\beta$ naphthylacetate (Merck, Darmstadt).

ALI activity was assayed kinetically by the cresol red method (Burlina and Galzigna, 1973a). Lipase activity was measured by the turbidimetric method of Burlina and Galzigna (1973b) with triolein (Sigma, St Louis) as a substrate.

All the above determinations were carried out at $21^{\circ} \mathrm{C}$ using an Eppendorf filter photometer.

Microsomal NADPH ${ }_{2}$-dependent oxidase activity was assayed polarographically with a Gilson GME oxygraph attached to a Sargent SR recorder (Slater, 1968) with orcinol (Merck, Darmstadt) as a substrate.

\section{Results}

Preliminary experiments showed that TCP had a significant effect after three days' treatment, on the activity of most of the enzymes tested.
Table 2 Inhibition of esterase activity by TCP. Liver microsomes were incubated with $0.13 \times 10^{-4} \mathrm{mg} \mathrm{TCP} / \mathrm{g}$ microsomal protein for 5 min at $21^{\circ} \mathrm{C}$. The results (mean and range of 5 experiments) are expressed as a percentage of the control values in Table 1

\begin{tabular}{llll}
\hline Enzyme & Substrate & $\begin{array}{l}\text { Microsomes } \\
(\% \text { inhibition })\end{array}$ & Serum \\
\hline ACC & Acetylthiocholine & $47(35-60)$ & $33(25-40)$ \\
CHE & Butyrylthiocholine & $92(80-100)$ & $87(79-99)$ \\
ALI & Ethylbutyrate & $27(20-32)$ & $\overline{15}(12-18)$ \\
ARE & $\beta$-naphthylacetate & $25(20-33)$ & 15 \\
\hline
\end{tabular}

Table 1 shows the normal levels of the specific enzyme activities in serum and both liver and brain microsomes of male and female rats under normal conditions.

Table 2 shows the percentage inhibition of some enzymes present in rat liver microsomes and serum after incubation with TCP in vitro.

Table 3 shows the most important changes in enzyme activity observed in male rats after i.p. injection of $2 \cdot 8 \mathrm{~g} \mathrm{TCP} / \mathrm{kg} /$ day for 3 days.

Table 4 summarises the results obtained after dermal application of TCP and inhalation of nhexane.

The Figure illustrates the effect of i.p. injection of TCP and n-hexane on microsomal $\mathrm{NADPH}_{2}-$ dependent orcinol oxidase.

\section{Discussion}

The effect of intraperitoneal TCP on serum and microsomal esterases of liver and brain is particularly evident when male rats are used. Table 3 shows that, compared with the normal values shown in Table 1, ACC and CHE are significantly lowered in rat serum after TCP treatment. Microsomal activity shows significant reduction of liver ACC, CHE and ALI and a significant increase in liver ARE attributable to TCP. Brain ACC and ALI activity is also significantly reduced while ARE activity is increased.

Table 2 summarises the effect of TCP added in vitro on liver microsomal ACC, CHE, ALI and ARE,

Table 1 Specific esterase activities (mean $\pm S E$ ) in male $(M)$ and female $(F)$ rats under normal conditions. Serum activities are expressed as $\triangle A / \mathrm{min} /$ litre serum while microsomal activities are given as $\Delta A / \mathrm{min} / \mathrm{g}$ protein. Observations on 10 male and 10 female normal rats

\begin{tabular}{|c|c|c|c|c|c|c|}
\hline \multirow[t]{3}{*}{ Enzyme } & \multicolumn{2}{|c|}{ Activity in serum } & \multicolumn{4}{|c|}{ Activity in microsomes } \\
\hline & \multirow[b]{2}{*}{$M$} & \multirow[b]{2}{*}{$\boldsymbol{F}$} & \multicolumn{2}{|l|}{ Liver } & \multicolumn{2}{|l|}{ Brain } \\
\hline & & & $M$ & $F$ & $\boldsymbol{M}$ & $\boldsymbol{F}$ \\
\hline $\begin{array}{l}\text { ACC } \\
\text { CHE } \\
\text { ARE } \\
\text { ALI }\end{array}$ & $\begin{array}{r}61 \cdot 01 \pm 3.79 \\
20.21 \pm 2.84 \\
3.03 \pm 0.13 \\
3.04 \pm 0.13\end{array}$ & 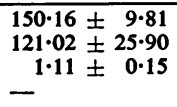 & $\begin{array}{l}39 \cdot 31 \pm 5 \cdot 69 \\
50 \cdot 23 \pm 2 \cdot 53 \\
35 \cdot 13 \pm 9 \cdot 17 \\
23 \cdot 14 \pm 6.64\end{array}$ & $\begin{array}{r}56 \cdot 41 \pm 11 \cdot 72 \\
36 \cdot 36 \pm 6 \cdot 32 \\
88 \cdot 22 \pm 18 \cdot 98 \\
6 \cdot 15 \pm 1 \cdot 26\end{array}$ & $\begin{array}{r}267.63 \pm 40.82 \\
50.24 \pm 12.02 \\
31.08 \pm 6.01 \\
8.09 \pm 1.89\end{array}$ & $\begin{array}{r}200 \cdot 03 \pm 25 \cdot 60 \\
23 \cdot 41 \pm 3 \cdot 79 \\
35 \cdot 32 \pm 4 \cdot 43 \\
11 \cdot 12 \pm 2 \cdot 53\end{array}$ \\
\hline
\end{tabular}


Table 3 Esterase activity of serum, liver and brain microsomes of 20 male rats after intoxication with TCP $(2 \cdot 8 \mathrm{~g} / \mathrm{kg} /$ day for 3 days). The results (mean and $S E)$ are expressed as a percentage of the control values in Table 1

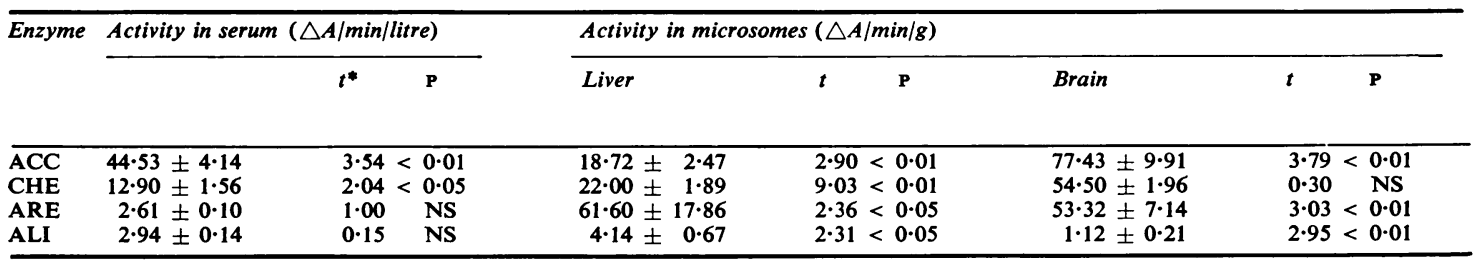

*Significance of differences by Student's $t$ test: $\mathbf{P}=$ probability.

Table 4 Effect of TCP applied dermally and n-hexane administered by inhalation on serum cholinesterase and microsomal arylesterase. The serum data are the means of six values while the values of the microsomal enzyme are relative to the mean of two observations on pooled organs of six rats. Serum activities and microsomal activities are given as a percentage (mean and range) of the values of the controls. TCP indicates the rats treated with TCP applied dermally (6), $H$ those treated with n-hexane (6) and TCP $+H$ (n-hexane) those pretreated with TCP (6). For this experiment a total of 24 male $(M)$ and 24 female $(F)$ rats was used

\begin{tabular}{|c|c|c|c|c|}
\hline \multirow[t]{2}{*}{ Source of enzyme } & \multirow[t]{2}{*}{ Treatment } & \multicolumn{3}{|c|}{ Enzyme activity (\%) } \\
\hline & & $A C C$ & $C H E$ & $A R E$ \\
\hline $\begin{array}{c}\text { *Serum } \\
\mathbf{M}\end{array}$ & $\begin{array}{l}\text { TCP } \\
\text { TCP }+\mathbf{H} \\
\mathbf{H}\end{array}$ & $\begin{array}{l}38(32-46) \\
38(30-49) \\
97(74-121)\end{array}$ & $\begin{array}{c}40(25-51) \\
40(27-50) \\
120(70-165)\end{array}$ & - \\
\hline $\mathbf{F}$ & $\begin{array}{l}\text { TCP } \\
\text { TCP }+H \\
\mathbf{H}\end{array}$ & $\begin{array}{l}27(14-40) \\
18(14-21) \\
41(25-58)\end{array}$ & $\begin{array}{c}70(67-74) \\
29(19-38) \\
119(97-140)\end{array}$ & - \\
\hline $\begin{array}{l}\text { * } \text { Liver microsomes } \\
\mathbf{M}\end{array}$ & $\begin{array}{l}\text { TCP } \\
\text { TCP }+H \\
\mathbf{H}\end{array}$ & $\begin{array}{c}57(48-65) \\
71(57-85) \\
102(90-114)\end{array}$ & $\begin{array}{l}142(118-160) \\
157(128-186) \\
180(142-218)\end{array}$ & $\begin{array}{l}410(344-476) \\
210(185-234) \\
158(124-193)\end{array}$ \\
\hline $\mathbf{F}$ & $\begin{array}{l}\text { TCP } \\
\text { TCP }+\mathbf{H} \\
\mathbf{H}\end{array}$ & $\begin{array}{l}59(50-68) \\
27(20-33) \\
72(61-83)\end{array}$ & $\begin{array}{l}75(60-91) \\
46(35-57) \\
39(28-50)\end{array}$ & $\begin{array}{c}1300(650-1950) \\
750(550-949) \\
1250(950-1551)\end{array}$ \\
\hline $\begin{array}{l}\text { * } \text { Brain microsomes } \\
\mathbf{M}\end{array}$ & $\begin{array}{l}\mathrm{TCP} \\
\mathrm{TCP}+\mathrm{H} \\
\mathbf{H}\end{array}$ & $\begin{array}{l}64(55-74) \\
132(115-149) \\
177(154-200)\end{array}$ & $\begin{array}{c}61(51-71) \\
89(76-102) \\
105(89-121)\end{array}$ & $\begin{array}{c}70(50-91) \\
1600(1420-1781) \\
20(9-31)\end{array}$ \\
\hline $\mathbf{F}$ & $\begin{array}{l}\text { TCP } \\
\mathbf{H}\end{array}$ & $\begin{array}{c}150(138-163) \\
107(99-115) \\
93(81-105)\end{array}$ & $\begin{array}{l}240(170-310) \\
270(210-330) \\
460(380-540)\end{array}$ & $\begin{array}{c}100(70-130) \\
1200(950-1450) \\
1400(1050-1750)\end{array}$ \\
\hline
\end{tabular}

* Range in parentheses.

**Values relative to the two pools in parentheses.

and shows that all enzyme activities are inhibited to a varying extent by TCP. This implies that the increased enzyme activity observed after i.p. injection is related to mechanisms which differ from those typical of enzyme inhibition.

The use of a different route of administration of TCP (dermal application) and treatment with nhexane gave the results summarised in Table 4. Serum ACC and CHE are inhibited by TCP in both males and females, and n-hexane seems to potentiate this inhibition in the serum of female rats.

With regard to microsomes, TCP appears to inhibit their ACC activity in liver and brain of male rats. However, there is a marked increase in male liver microsomal ARE activity following TCP administration, and an increase in ARE of male brain microsomes following TCP plus $n$-hexane administration. Microsomal ACC and CHE activity in liver of female rats is generally inhibited by TCP while ARE activity is markedly increased. $\mathrm{N}$-hexane seems to potentiate the inhibitory effect on female liver microsomal ACC and appears to increase female liver microsomal ARE. Female brain microsomal ARE is also markedly increased by TCP plus $\mathrm{n}$-hexane, while $\mathrm{n}$-hexane alone increases female brain ARE and CHE activity, which is also increased by TCP alone.

This increased microsomal enzyme activity sug- 


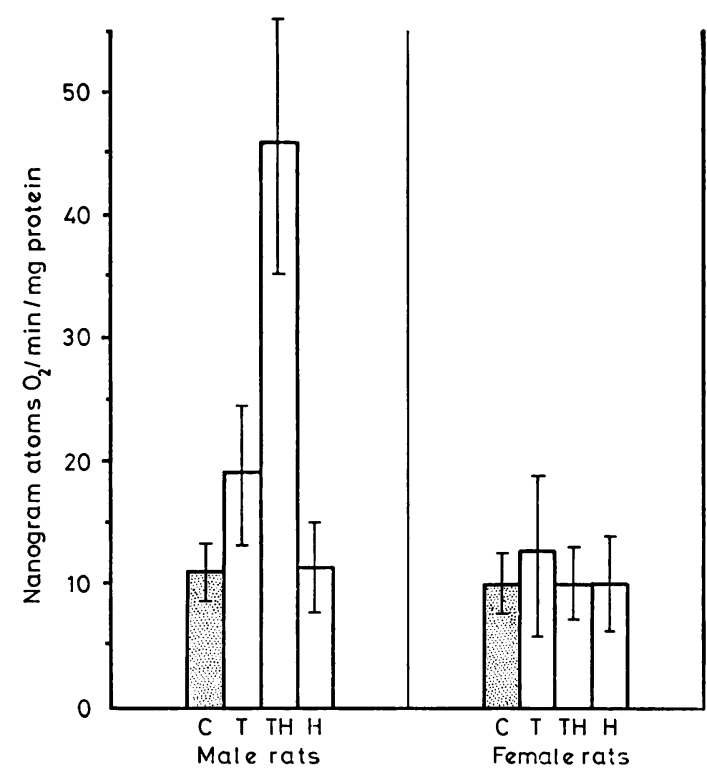

Figure $\mathrm{NADPH}_{2}$-dependent orcinol oxidase activity of rat liver microsomes. TCP and n-hexane were given by i.p. injection to 30 male and 30 female rats at a dose of $2 \cdot 8 \mathrm{~g} / \mathrm{kg} /$ day for 3 days. The activity is measured as nanogram atoms $O_{2} / \min / \mathrm{mg}$ protein. $C=$ control; $T=$ $T C P ; T H=T C P+n$-hexane and $H=n$-hexanetreated group. Vertical lines show mean values (at intersection of vertical with histogram) and standard deviations.

gests that some phenomenon of enzyme induction may be involved in the response to treatment with TCP, and that this differs slightly between the sexes.

The determination of $\mathrm{NADPH}_{2}$-dependent orcinol oxidase activity, which is typically sensitive to induction, showed that TCP increases oxidase activity in male rats and that the increase is highly potentiated if $n$-hexane is given together with TCP. No such changes occur in females.

A possible mechanism of enzyme induction, sexdependent and superimposed on the inhibitory effects might explain the increase of microsomal ARE. It is well known that TCP is metabolised in rats by hydroxylation and cyclisation catalysed by microsomal enzymes (Eto et al., 1962).

The data on microsomal $\mathrm{NADPH}_{2}$-dependent orcinol oxidase activity show that enzyme induction may possibly result from TCP and TCP plus nhexane treatment in male rats. This is in agreement with the increase of ARE activity observed in male but not in female rats.

The CHE inhibition, which is probably the most important effect of TCP in female rat liver, may be masked in males by a concomitant enzyme induction.
The possible synergism between TCP and n-hexane seems, in fact, to occur to a different extent in the two sexes.

These results and conclusions corroborate the claims of Johnson (1975) in his critical appraisal of the problem of delayed neuropathy by organophosphorus esters. The present study enabled us to identify the specific esterases which, in a group of different esterase enzymes, are primarily affected in TCP intoxication.

We wish to thank Dr L. Galzigna for his help and advice.

\section{References}

Aldridge, W. N., and Barnes, J. M. (1961). Neurotoxic and biochemical properties of some triaryl phosphate. Biochemical Pharmacology, 6, 177-188.

Aldridge, W. N., and Barnes, J. M. (1966). Further observations on the neurotoxicity of organophosphorus compounds. Biochemical Pharmacology, 15, 541-548.

Aldridge, W. N., and Reiner, E. (1972). Enzyme Inhibitors as Substrates. North Holland: Amsterdam.

Burlina, A., and Galzigna, L. (1972). A new and simple procedure for serum arylesterase. Clinica Chimica Acta, 39, 255-257.

Burlina, A., and Galzigna, L. (1973a). Standardizzazione di un metodo per la determinazione spettrofotometrica dell'attività aliesterasica. Quaderni Sclavo Diagnostica, 9, 85-90.

Burlina, A., and Galzigna, L. (1973b). A turbidimetric procedure for the determination of lipase activity. Clinical Chemistry, 19, 384-387.

Dubois, K. P. (1972). Interaction of chemicals as a result of enzyme inhibition. In Multiple Factors in the Causation of Environmentally Induced Disease, pp. 95-107. Edited by $\mathrm{H}$. Douglas, K. Lee and P. Kotins. Academic Press: New York and London.

Ellman, G. L., Courtney, K. D., Andres, V., and Featherstone, R. M. (1961). A new and rapid colorimetric determination of acetylcholinesterase activity. Biochemical Pharmacology, 7, 88-95.

Eto, M., Casida, J. E., and Eto, T. (1962). Hydroxylation and cyclization reactions involved in the metabolism of tri-ocresyl phosphate. Biochemical Pharmacology, 11, 337-352.

Gornall, A. G., Bardawill, C. J., and David, M. M. (1949). Determination of serum proteins by means of the biuret reaction. Journal of Biological Chemistry, 177, 751-766.

Johnson, M. K. (1975). The delayed neuropathy caused by some organophosphorus esters: mechanism and challenge. Critical Reviews in Toxicology, 3, 289-316.

Peretti, A., and Bombi, G. G. (1975). Produzione di atmosfere standard e loro applicazione in tossicologia inalatoria. In Proceedings of the XXXVIIIth Congress of the Italian Society of Industrial Medicine, 20-22 October 1975, Padova, Italy, volume 1, pp. 75-79. Edited by S. R. L. Kurtis. Italian Society of Industrial Medicine: Milan.

Schneider, W. C. (1964). In Manometric Techniques, 4th edition, pp. 188-189. Edited by W. W. Umbreit, R. Burris, and J. F. Stauffer. Burgess Publishing Co: Minneapolis.

Slater, T. F. (1968). The inhibitory effects in vitro of phenothiazines and other drugs on lipid peroxidation systems in rat liver microsomes and their relationship to the liver necrosis produced by carbon tetrachloride. Biochemical Journal, 106, 155-160. 